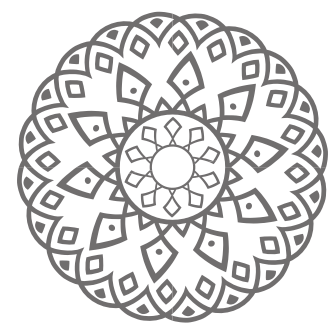

\title{
Community-Based Recovery For Sexual Violence Victims: The Case of Hapsari
}

\author{
Atikah Rahmi \& Hotma Siregar
}

\begin{abstract}
Abstrak: Korban kekerasan seksual mengalami kekerasan secara fisik, psikologis, ekonomi, dan sosial. Hal itu yang menyebabkan trauma dan mengancam kehidupan mereka. Namun, sampai saat ini belum ada kebijakan yang mendukung proses pemulihan korban kekerasan seksual. Untuk itu, didirikan organisasi Hapsari yang mendukung layanan berbasis komunitas untuk menekan kekerasan terhadap perempuan dan anak, melindungi korban, dan mengumpulkan dukungan untuk keberlangsungan layanan pemulihan korban kekerasan. Penelitian ini merupakan penelitian kualitatif dengan menggunakan wawancara sebagai teknik pengambilan data. Subjek dalam penelitian ini terdiri dari perempuan dan anak di Sumatera Utara. Penelitian ini menemukan bahwa upaya pemulihan berbasis komunitas seperti yang dilakukan Hapsari memberikan dampak signifikan terhadap korban dan mampu memberdayakan mereka untuk menjadi mandiri dalam mengambil keputusan dalam berbaur dengan masyarakat. Meskipun demikian partisipasi negara dalam memberikan perlindungan bagi korban, melalui kebijakan dan peraturan jauh dibutuhkan.
\end{abstract}

Kata kunci: hak korban, kekerasan seksual, pemulihan berbasis komunitas 
Abstract: Sexual abuse victims experienced physical, psychological, economic and social violence, which lead to trauma. However, there has been no systematic policy to support their recovery. This paper argues for the need for a recovery mechanism system for sexual violence victims, as implemented by Hapsari. This study employs a qualitative approach, with interviews as the means to obtain data. Subjects in this research included women and children in the North Sumatera. This research finds out that communitybased recovery has a significant impact on the victims, and is able to empower them to be independent in making a decision and blend with society. As a grassroots organization, Hapsari supports community-based services to reduce violence against women and children, protect victims and gather supports for the sustainability of recovery services. Apart from this, the state should also participate in protecting those people, especially in terms of policy and regulations.

Keywords: victims rights, sexual violence, community based recovery 


\section{Introduction}

This article explores a community-based recovery model for victims of sexual violence who experience the extraordinary impact of such violence. In principle, the state has a legal obligation to protect and promote the rights of the people including the rights of women and children who are the victims of sexual violence based on the constitution and the principles of Human Rights. As the ideology and constitution, every person has rights such as the rights of safety and life without violence. No one can seize others'right, including women and children's rights (Siregar, 2018). Therefore, violence occurred to women and children, especially sexual violence, is an offence of people's fundamental right, an assault of human dignity and discrimination that should be vanished (Muhammad Taufik Makarao, Wenny Bukamo, Syaiful Azri, 2013).

The victims of sexual violence generally are women, children, and disables (Jane R. Chapman in Luhulima, 2000: 78). Children are one of the sexual violence targets because of their weakness to fight against the offenders; and generally, they cannot understand what they are going through (Chomaria: 2014: 86). Women and children, as victims often experience more violence, both physically and mentally, at home and in the community (Alkhanif, 2019). The victims and their families experience prolonged suffering caused by sexual violence, in the form of trauma and depression. According to Fatahillah (Syukur, 2011), it is not easy for the victims of violence to talk about their bad experiences, because of doubts whether their stories will be trusted and supported; and fear the violence will recur (Sarong \& Lubis, 2019). In the case of domestic violence, for example, the victims worry that they are not trusted when reporting the violence that occurred. This is because the incidents take place in the domestic realm. Likewise, the case of sexual violence perpetrated by a family member-for example, a father against his child-often leads to re-victimization.

Criminal law enforcement system, mainly to prevent sexual-related violations, is still weak. Generally, sexual crimes are revealed when the victim complains, or the victim's family reports sexual harassment. The absence of prevention efforts and the absence of severe penalties for perpetrators of sexual harassment cause these acts continue to repeat. (Jaka Susila, 2019) 
Abdul Muhid et al. (2019) argue that violence has a prolonged lousy impact on the victims. First, the victims often experience physical trauma caused by physical violence such as fractures, lacerations and head trauma, various pain disorders, sexually transmitted infections, and unwanted pregnancies. Second, psychological violence has negative impacts the victims'psychology such as depression; mental pressure; feeling a family disgrace; and a tendency to be blamed, untrusted, and easily attacked by a disease. The victims may also lose economic benefits and lose some of their human rights and other sufferings. 3) Mental health impacts include the increased risk of depression, anxiety, posttraumatic disorders, and suicide. Furthermore, the most detrimental impacts include pregnancy, premature birth, and low birth weight.

Trauma and depression experienced by victims can even have a negative effect because of the tendency of victims to become perpetrators of sexual violence when they reach adulthood (Ratih Probosiwi, Daud Bahransyaf, 2015). This was also revealed by Faulkher (2003), in Zahra, (2007) that $31 \%$ of female convicted sexual violence in America were the victims of sexual violence in their childhood. $95 \%$ of sex workers were sexual violence victims in their childhood. $40 \%$ of child sexual assailants and $76 \%$ of serial rapists also experienced sexual violence in childhood.

The impact of these injuries makes it difficult for the victims to reveal the violence they had experienced. In fact, according to Phebe Illenia S, Woelan Handadari, most sexual violence victims suffer post-traumatic stress disorder (PTSD). PTSD is an anxiety syndrome, autonomic lability, emotional irreversibility and flashbacks of a harrowing experience after physical and emotional stress that goes beyond the limits of endurance of ordinary people. Victims need a recovery process from PTSD so that their quality of life can improve and they do not continue to regret the traumatic events. However, healing PTSD is not easy because healing the victims from trauma does not make them forget the incidents. (Phebe Illenia, Woelan Handardari, 2011).

Based on the description above, the purpose of this study is to explain the importance of recovery efforts for women and children who are the victims of violence by relying on community participation. It is expected that the community can empower the victims to make decisions about themselves; be accepted in the community, and possess 
soft skills for their lives. Several studies on sexual harassment victims have been found, including research conducted by Dian Dwi Nur Rahmah, Sita Iriyanti et al., (2017), on Bibliotherapy: Self Help Book to increase Self Concepts for sexual Harassment Victims. This study focuses on creative communication techniques with child victims of sexual violence through quantitative methods with an experimental approach. Meanwhile, Penny Naluria Utami (2016) explained the optimization of the sexual violence victim's true fulfilment through integrated service centers, which emphasized the importance of P2TP2A in the regions. This particular study, on the other hand, is a qualitative study that portrays the object of research transparently based on secondary data supported by primary data. The primary data was obtained through interviews with several institutions that are concerned with the issue of women and children. These institutions are Happsari, Lembaga Perlindungan Perempuan dan Anak (LPPA) Labuhan Batu Main, and Lembaga Bantuan Hukum Asosiasi Perempuan Untuk Keadilan (LBH APIK) Medan as well as the P3AM Office in Binjai City. Interviews with figures from those institutions reveal a useful model in handling victims of sexual violence in North Sumatra that relies on community participation; and synergy with the government and service provider institutions.

\section{Discussion}

\section{Sexual Violence Is Gender-Based Violence}

Violence against women, in principle, is an act of enforcing the will of women by using women's bodies and sexuality as their objects. The term violence against women has been voiced globally since the last three decades (Muhtaz,2013). The occurrence of violence against women is a result of labeling (stereotype), marginalization and subordination of women. As clearly stated in the World Conference report (1995) in Beijing, in item 113, the term "violence against women" means any act of gender-based violence that results in, or is likely to result in, physical, sexual or psychological harm or suffering to women, including threats of such acts, coercion or arbitrary deprivation of liberty, whether occurring in public or private life."

Sexual violence is the most severe consequence of gender inequality. Violence against women is a form of violation of human rights that can 
occur to anyone, across the social, economic and educational status. Violence experienced explicitly by women, begins with the existence of unequal gender relations. Empirical facts show that women are the majority group among the victims of violence in various forms. These include physical violence, psychological violence, sexual violence, neglect, exploitation and other kinds of violence (Ema Mukarramah, Tri Dewiyanti (Ed): 2018: 5), (Utami, 2016).

The definition of sexual violence, as proposed by the National Commission on Violence Against Women for the Elimination of Sexual Violence Bill (Rancangan Undang-Undang Penghapusan Kekerasan Sexual), is "any derogatory, insulting, or attacking act or another kind of acts against some one's body, sexual desire, and/or reproduction function with force, against her/his will, causing the inability to give consent freely due to unequal power relation or gender relation resulted in or may result in physical, psychological, or sexual suffering, or economic, social, cultural, and political disadvantages". Sexual violence is classified into several forms, namely sexual harassment, sexual control, rape, sexual exploitation, sexual torture, other inhumane treatment or punishment, targeting one's body and sexuality and/or reproductive organs.

The physical presence of women, which are generally weaker than men, has implications for labeling that women are also weak in all respects. This condition is often used by men to discriminate against women or marginalize women, so they do not involve women in strategic roles. On the contrary, women are in the position of subordination and marginalization. As a result of the labeling, men often exploit their power to commit violence against women physically, psychologically and sexually.

Patriarchal culture, which is a culture that is centered on men and in the interests of men, is the most significant cause of violence against women. (Noviani UZ, Arifah R, Cecep, Humaedi S: 2018). An ideology that legitimizes men's authority and superiority. The belief that women are soft and weak creatures by nature; inferior, with their position is under men and made to serve men's sexual desires and so on, has placed women as if they were allowed to be treated according to with men's wishes, including employing violence.

This patriarchal ideology influences the way of thinking of society, the interpretation of religious texts and policy-making process. Thus, 
ideology becomes the reason for sexual violence acts against women. Inequality based on patriarchal ideology potentially create injustice, subordination and domination over women (Abdul Muhid et al: 2019). This imbalance is the primary source of violence against women. Through patriarchal culture, many systems and policies formulated without accommodating the needs and interests of women

The community often blames victims when sexual violence occurs in the form of rape. When violence against women happened, the community is often not by the side of the victims. They do not protect the victims or provide supports for them. Sometimes the public blurted out words that blame the victims. Victims often do not obtain partiality. They are blamed and considered to cause rape due to their clothing. For example, women are blamed for the rape they suffered because they do not wear hijāb. In this case, women are deemed to create "slander" (teasing and triggering male sexual desires. Such an unexpected attitude is developed in society. Women with hijāb have also been victims of violence. In some cases, women are criminalized by using defamation law or Electronic Information and Transaction law, such as what was happened to Baiq Nuril.

With regards to religious teaching, all religions aim to free people from suffering, oppression and ignorance, as well as to uphold justice, share love, spread knowledge. These are built on humanity principles, especially: respecting human dignity, equality, liberation, and justice, as stated in the Qur'ān, sūrah al Isrā'(70):

"And We have certainly honored the children of Adam and carried them on land and sea and provided for them of the good things and preferred them over much of what We have created, with (definite) preference.". (Q.S. Al-Isrä̀'(17):70)

Besides, the Qur'ān also mentions in sūrah Al Hujurāt (11):

"O you who have believed, let not a people ridicule [another] people; perhaps they may be better than them, nor let women ridicule [other] women; perhaps they may be better than them. And do not insult one another and do not call each other by [offensive] nicknames. Wretched is the name of disobedience after [one's] faith. And whoever does not repent - then it is those who are the wrongdoers".(Q.S. Al-Hujurāt (49):11).

Based on that, KUPI (Indonesian Women's Ulama Congress) issued a fatwa, in 2018, related to sexual violence. The fatwa mentioned 
that sexual violence both inside and outside of legal marriage, is haram (prohibited) because it violates human rights guaranteed by Islam (Armia, 2018). Therefore, all parties are required to take preventive measures, and when they do, they must consider variety of measures.

\section{Recovery as a Right to the Victims of Sexual Violence}

The rights of victims of sexual violence include the right to treatment, protection and recovery, with the aim at changing the condition of the victim to the better, more dignified and prosperous. The right is centered on the needs and interests of victims that are multidimensional, sustainable and participatory. The fulfillment of these rights is aimed at preventing the recurrence of sexual violence and the continuing impact on victims. A victim's rights to recovery include; physical, psychological, economic, and socio-cultural recovery, as well as restitution.

Nurhasyim (2016) defines recovery as a process of meeting the needs of victims in crisis conditions and the needs of victims to be able to socialize with others in their environment, including; fulfillment of medical treatment, psychological, legal, psycho-social assistance in the form of the return and reintegration of the victims to their families and community.

Government Regulation No. 4 of 2016 concerning the Implementation of Recovery Cooperation of Victims of Domestic Violence only includes recovery of victims of domestic violence as an effort to empower the victims, physically and psychologically. Meanwhile, the implementation of the recovery referred to in this government regulation is limited to services and assistance to victims, but not yet reaching other aspects such as social, economic and political aspects of the victims.

Meanwhile, the National Women's Commission, a state institution focusing on human rights issues, especially for women and children, gives a different meaning to recovery. According to the National Women's Commission, recovery is the needs of victims of violence in broad manners. The recovery is not only related to the medical, legal and psycho-social treatment but also includes the process of victim recovery to regain their power. With this, they can make decisions in 
their lives and be able to return to their role in society as fully human beings. Recovery, according to the National Commission on Violence Against Women, also includes the fulfillment of their fundamental rights as citizens, such as education, health, population and political rights. This also includes reintegration, compensation and prevention of violence so that it does not recur. This has become an integral part of the recovery process in a broad sense (the National Women's Commission., n.d).

The policy on recovery is not integrated with a statutory regulation related to sexual violence but is spread in several laws and regulations. These include Law No. 23 of 2004 concerning the Elimination of Domestic Violence; Law No. 13 of 2006 concerning Protection of Witnesses and Victims; Law No. 21 of 2007 concerning Eradication of Trafficking in Persons; Law No. 35 of 2014 concerning Amendments to Law N0. 23 of 2002 concerning Child Protection; and the Regulation of the State Minister for Women Empowerment and Child Protection No. 01 of 2010 concerning Minimum Service Standards (SPM) for Integrated Services for Women and Children Victims of Violence. This latest regulation requires the government to establish an integrated service center for the empowerment of women and children (P2TP2A).

Efforts to protect women and children, who are victims of sexual violence, to fulfil their rights, are still difficult. This is because the existing law and regulations are inadequate and even often discriminate the victims of sexual violence. For this reason, new legislation must be formulated by inserting the perspective of victims, gender, children and human rights, as in the Elimination of Sexual Violence (PKS) Bill. The Bill contains the explanation of the types of sexual violence crimes and extends the punishment of perpetrators, such as proper restitution and rehabilitation. This is expected to improve the procedural law for criminal justice integrated with the recovery process, which includes physical, psychological, economic and social recovery. These laws and regulations must also be able to encourage the improvement of the legal infrastructure and increase the capacity and professionalism of law enforcement officials, especially in interviewing victims, as well as being able to remove or eliminate the stigma against victims of sexual violence. Such stigma can damage and hinder the rights to justice and truth. 
Islam also obliges the State to guarantee the fulfillment of the rights of every citizen, especially the rights of victims of sexual violence (Armia, 2019). The Indonesian Ulama Women's Congress (KUPI), in its fatwa, urges the state to fulfill the rights of victims and protect victims so that their future remains secure and that they can build a decent life. "The state must be present in sexual violence cases to ensure the fulfilment of the rights of citizens, including victims." KUPI also condemns the behavior of state officials that complicate the legal process for victims of sexual violence, especially those who discriminate against victims and even become perpetrators of sexual violence. "If the state neglects, complicates, and wastes the rights of citizens, especially victims of sexual violence, the state has been wronged and violates the constitution. Not only that, if a state authority commits sexual violence, then the punishment should be more severe (taqlidu al uqübah)."

\section{Community-Based Recovery Models for Women and Children as Victims of Violence}

Violence experienced by victims is a traumatic event and requires serious treatment for recovery. Violence has caused various injuries to victims. Violence causes the victims to lose the essential things in their lives and has a severe impact on their lives in the future. (Nursariani, Faisal: 2018). The impact that is not light on women victims of violence, as the trace will be there throughout their lives. This, in turn, will affect the way of acting and thinking of the victims. Shame, fear, feelings of inferiority and even stress will be experienced by women victims of violence. Based on an interview with Indrawaty Sinaga, the chairperson of Labuhan Batu Induk Women's and Child Protection Institute (LPPA), it was explained how the conditions and impacts of violence experienced especially by violence victims who are children. Sinaga said:

After violence occurred, victims experience severe psychological effects. Victims are often frightened. (They) do not want to meet with people, even with their parents. Sometimes, (they) do not want to escape because they are haunted by the conditions they experienced before. Victims also become whiny, do not want to get along and tend to be a shy child - the impact of violence, especially rape. Also has an impact on the future of victims who have had to experience an unwanted 
pregnancy (KTD). Physical violence experienced by the victim may heal in a matter of days or weeks. However, psychological injury is more profound and causes trauma, hysteria and depression. According to Indrawati, in certain situations or maybe every day, victims/survivors often experience trauma so that when they start to do their daily activities, they often feel scared. Especially when someone touches a part of their body, they may cry and be scared. This trauma usually lasts a long time if no immediate recovery is made. Some rape victims are even reluctant to get married. Even if they can get married, they will find it difficult to have sex because it reminds them of unfortunate events in the past. (an interview with Indrawaty Sinaga, May 2019).

Sri Rahayu maintained:

in addition to being traumatized, the victims had also experienced hysteria such as sudden screaming when nothing happened. (This is) because the victims reminded of an unfortunate incident, they experienced. The victims/survivors suddenly cried and stopped when they felt comfortable. Sometimes when the victims/survivors see another person who is similar to the perpetrator, he can make them scream for help. (interviewed with Sri Rahayu; Mei 2019).

The depression experienced by the victims causes severe disruption to their body and psychology. The victims tend to experience selfblame, guilty feeling, avoiding and hiding, instability and oversensitive. Someone with depression is usually challenging to live and feels afraid to do anything. When they are sleeping, they often have unclear dreams. This is, especially when the victims experience a pregnancy after sexual violence. If the problem is not resolved soon, they will have a mental illness; hurt themselves, and may commit suicide. Neglected trauma will cause new problems that will create another new trauma-conditions like this like a circle that has a no-tip base. Therefore, recovery is an urgent step to break the vicious cycle (Purnawan Kristanto, Kompasiana.com).

Based on the impact of violence experienced by victims, recovery is an urgent effort to recover victims from prolonged trauma as a result of the violence they experienced. The goal of recovery is to help the victims know what kind of response is appropriate in such a traumatic condition. Thus, the victims can make decisions and understand the continued impact of their own decisions. This, in turn, can help the recovery process. The victims will experience prolonged adverse effects without recovery efforts. The victims are vulnerable to prostitution, away from 
families, and the tendency of victims to choose shortcuts. Among them is revenge, become perpetrators of violence, and committing suicide.

The discriminatory response from the community has implications for new vulnerabilities that hamper the victim's recovery process. For this reason, the main challenge in providing recovery is how to make the victims not feel more depressed or re-victimized (repeated violence). A vital step to prevent this re-victimization is by building cooperation among service providers to give proper assistance to the victims according to their needs and choices. Lely Zailani from Hapsari explained in the interview on August 28, 2019, as follows:

In the victim blaming culture, the community greatly influences the attitude of the victims. (In this case, is) whether to report or not, whether to "open my mouth" or not. So, the community that supports the victims is very important, and that is what we have prepared for a long time. In Hapsari, the process of victim recovery is not placed only in the context of the case, but also as the part of the organization and women empowerment. So, until the recovery process, we have to involve the community (environment) where the victims live. If for safety reasons the victim cannot live in their environment, we have prepared another "community" that is aware of the victims and the cases they have experienced. There have been cases where victims feel unsafe if they still live in their homes and neighborhoods because their husband wants to kill them. So we brought them to Bambat village, and it happened that there was a family here. There was one incident, a husband caught up with a victim. Instead, he was rejected by the community, as the community based-service environment is as a place for victims to take shelter for a while (Lely Zailani, 2019).

Supports from family and community much help restore the victims'confidence and make them feel secure. This is because they believe that they are not alone in dealing with their problems. When a person recovers, she will realize that the problems she experienced after the traumatic event are reduced. The problem is not as severe as previously experienced and not bothering her as it was. The victim also began to experience empowerment and be motivated to take positive steps for her life and the lives of others around her. Each victim must undergo a process of recovery, which is varied depending on the situation and physical and psychological conditions.

Community-based recovery prioritizes community participation, where the community plays an essential role in the planned steps. Social 
support from families, especially children and parents as well as people in the neighborhood also help to restore the victims'condition. In addition to emotional supports provided by the people closest to the victims, supports in terms of access to the economy, social roles, and new responsibility at the consort (WCC) and home are crucial to help them find their happiness again (Abdul Muhid, Lia Masfiatul Khorirah et al.: 2019).

In addition to active participation from the community, this approach focuses on the community as a whole. One of the institutions that have implemented a community-based recovery model in North Sumatra is Hapsari, a grassroots institution that is concerned with women's issues. The Indonesian Women's Union Association (Hapsari), which was founded in 1990 in Sukasari Village, Perbaungan District, North Sumatra, is one of the institutions that concentrate on sexual violence cases. One of the programs promoted by Hapsari is a grassroots community-based service (layanan berbasis komunitas/LBK) that aims to prevent violence against women and children; protect victims, and gather support for the sustainability of services. Community-Based Services, which was established in 2014, has become a medium for a joint movement among Hapsari and the village government, district government and service provider institutions in North Sumatra. LBK handled as many as 487 cases as of June 2014-June 2019.

The Community-Based Service Program is driven by a local grassroots women's organization, Serikat Perempuan Indonesia (SPI), which is a member of Hapsari. This organization is established based on the Decree of the village head. Administrators are given appropriate training needed for handling cases. For the empowerment, Hapsari pushed the issuance of a Village Regulation (PerDes) to establish a budget allocation for handing women's violence by LBK. The LBK program includes case handling, dissemination of information related to violence against women, capacity building for administrators, policy and budget advocacy (PerDes) and others, according to village needs.

Through community-based recovery, victims are invited together to explore the root causes of the trauma they experienced. The characteristics of community-based recovery are: to be contextual; from and by the community; started from the grassroots; sustainable; based on the needs and carried out by the community. Participation of organized community members is instrumental in providing supports and assistance needed by victims. These include referring cases of 
violence found in the community to the institutions that can assist professionally, such as Lembaga Bantuan Hukum Asosiasi Perempuan Indonesia Untuk Keadilan (LBH APIK) Medan, for legal assistance. The community can also help by not discriminating against victims and providing opportunities for victims to socialize with other members of the community. This will help restore the victims; confidence and make them feel strong because they believe that they are not alone in dealing with the problem. (Lely Zailani, 2019)

Lely Zailani explained: "in the process of community-based recovery, it does not stop until the case is handled and "finished". Victims will be part of the community that was built earlier. They will be included in relevant community activities. There are survivors'forums. Some victims, then, participate in paralegal training and begin helping other victims. There are 30 volunteers and 20 paralegals who assist victims in the recovery and handling cases to court. LBK has developed a collaboration with the government of Denai Kuala Village in Pantai Labu Deli Serdang sub-district. This is considered as a village innovation because it had succeeded in triggering the issuance of the Regulation on the Protection of Women and Children. Whereas in Serdang Bedagai District, there are Bingkat Village and Pegajahan Village which have adopted LBK as a village innovation program launched by the Village Innovation Exchange in 2019.

What Hapsari has done is in line with the concept of recovery developed by Komnas Perempuan since 2005. This recovery is a process to support women victims of violence to be strong, capable and empowered in making decisions and seeking a just, dignified and prosperous life. The principle that must be emphasized in the recovery is that recovery is a continuous and personal process, according to the needs of the different victims. The path and method of recovery can change according to the needs and decisions of the victims. (Komnas Perempuan: 2018).

Aside from being oriented towards women victims, recovery must also be based on the rights of victims. These rights include the right to truth, justice, recovery, non-repetition of violent incidents, and as an integral part of human rights enforcement. The four victims'rights are multidimensional, which are interrelated and influence each other. Therefore, to make victims recover, strive for aspects of physical and psychological health, economic resilience, and community acceptance 
are not separated from the efforts to present recognition that the violence experienced by the victim is the right. This also needs to be followed by building a sense of justice in the victim, and guarantee that the violence experienced will not recur. ((Ema Mukarramah, Tri Dewiyanti (Ed): 2018: 86). Indrawaty Sinaga, the chairman of LPPA Labuhan Batu Induk, explained in an interview:

Recovery requires a mutually reinforcing and equal relationship between victims, advocates and the community. The companions help and facilitate the victims to be able to rediscover their strength so that the victims can make the best decision for themselves. The victims are given choices and informed the consequences of those choices, not orders or advice. Supports from family, religious figures and community are urgently needed by the victims to rise and be economically independent. The existence of Shelter / safe house is needed as a safe house for the victims in the recovery process and to empower them with soft skills. Through the shelter, victims are given recovery models such as the Labuhan Batu Induk Women's and Child Protection Institute, which uses a doodle therapy for children as victims of sexual violence while still also involving the role and participation of families and communities. "Families must provide great support to victims to be able to survive. Through this doodle therapy recovery model, victims are led to begin to think that what they experienced is something that is not right. While playing and given sweets, victims are encouraged to tell the bad events they experienced". (Indrawaty Sinaga, 2019).

The interview with Sierly Anita in May 2019 reveals several examples of case handling that employs community empowerment in the efforts of victim recovery. One of them is the case experienced by Peni from Binjai, who was the victim of domestic violence committed by her husband.

The husband doused the victim with caustic soda, which left wounds on the face and eyes until she could not see. Through P3AM Binjai city, the perpetrator was reported, but the police were not able to get him because he ran away. The victim suffered from physical and psychological injuries, and even the victim did not have a house, so she was forced to stay at her neighbor's house. For this reason, P3AM Binjai City synergized with P2TP2A Binjai City and LBH APIK Medan. Through LBH APIK Medan, the victim was reported to the Witness and Victim Protection Agency (LPSK) to get recovery assistance for victims, including their three children. LPSK approved the victim's recovery request, including the costs for the victim's eyes surgery and also the needs of her children. (Sierly Anita, 2019). 
The case above is a form of recovery that involves the participation of the government and also the community. Another case that is handled in synergy and involves public participation in the handling of rape cases by LPPA Labuhan Batu Induk. Indrawaty Sinaga explained in the interview in May 2019:

The 6th-grade child who was raped by her neighbor was pregnant. The school did not allow her to go to school anymore. LPPA Labuhan Batu Induk coordinated with the school and the Education Office to give permission for the child to stay in school. Finally, the school agreed. After completing the final exam in grade 6 , the child is evacuated to a safe house until she gave birth. LPPA Labuhan Batu Induk asked for supports and coordinated with the hospital so that she could get an excellent service at the hospital during labor. The victim, who in fact was an orphan and came from a low-income family, was taken to the orphanage by the postpartum family. At the same time, her confidentiality was also maintained, except for the primary caretaker at the orphanage. Thanks to the support of many people, the child was able to recover. Now, she is a High School student. ( Indrawaty Sinaga; 2019).

Through the role and participation of the community, victims find people who are willing to listen to their problems after experiencing sexual violence. The acceptance of the people around the victims is the beginning for them to find their lives again. Furthermore, when the victims are convinced that they are able to return to their lives, that is when the victims are able to portray themselves with their social duties.

\section{Conclusion}

Recovery aims to help sexual violence victims know what kind of response is appropriate in a traumatic condition. This can make the victims believe that they can make a decision and understand the impact of their own decision. The capability of the victims to make their own decisions is one of the things that helps the recovery process. The recovery of victims of violence, according to their version, is very dependent on four factors. First, the family is a reason to strengthen the victim or to provide adequate supports. Second, the victims need to work for their income resource to fulfil their needs. Third spiritual supports (religion, belief) can strengthen the victims so that they can get back from their downturn. Fourth, social participations or the availability of community supports are reinforcement strategy for 
victims. The participation and synergy of the government, institutions and the community are needed in the recovery process for women and children, who are the victims of violence. Community-based recovery has characteristics as follows: contextual, from and by the community, started from the grassroots, sustainable, based on needs and carried out by the community. The role and participation of the community are instrumental in providing supports and assistance that are following the needs of victims. Communities can take the role by providing opportunities for victims to socialize with fellow community members without discrimination. Thus, the victims become stronger and more confident in dealing with their problems. Through community-based recovery, victims will become part of the community together with other survivors and engage in community activities, including paralegal training and helping other victims.

\section{References}

Alkhanif, (2019). Women, Islam, And Modern Family Construction In The Perspectives Of Legal Pluralism In Indonesia. Petita: Jurnal Kajian Ilmu Hukum dan Syariah 4(2).

Armia, MS. (2018). Implementing Islamic Constitutionalism: How Islamic Is Indonesia Constitution?. Al-'Adalah. 15 (2).

Armia, MS. (2019). Public Caning: Should It Be Maintained or Eliminated? (A Reflection of Implementation Sharia Law In Indonesia). Qudus International Journal of Islamic Studies. 7(2).

Cecep, C., \& Humaedi, S. (2018). Dan Mencegah Tindak Kekerasan Seksual Pada Perempuan Dengan Pelatihan Asertif. Prosiding Penelitian dan Pengabdian kepada Masyarakat, 5(1):48-55.

Ema Makaramah, Kunthi Tri Dewiyanti (ed). Second Cetakan kedua (2018). Membangun Akses Keadilan Bagi Perempuan Korban Kekerasan: Perkembangan Konsep Sistem Peradilan Pidana Terpadu Penanganan Kasus Kekerasan Terhadap Perempuan (SPPT PKKTP). Komnas Perempuan: Jakarta.

El Muhtaj, M. (2008). Dimensi-Dimensi HAM. Mengurai Hak Ekonomi, Sosial, Budaya. Cetakan ke-3, Jakarta: PT Raja Grafindo Persada

Fatahillah, S. A. (2011). Mediasi Perkara KDRT (Kekerasan Dalam Rumah Tangga) Teori dan Praktek di Pengadilan Indonesia, Bandung: Mandar Maju.

Handadari, W. (2012). Pemulihan Diri pada Korban Kekerasan Seksual. Jurnal Insan Media Psikologi 13(2).

Hasyim, N. (2018). Menyoal Pemulihan Bagi Anak Korban Kekerasan Di Indonesia, Palastren Jurnal Studi Gender, 9(2):305-323. 
Ismantoro Dwi Yuwono, S. H. (2018). Penerapan Hukum Dalam Kasus Kekerasan Seksual Terhadap Anak. Bekasi: Media Pressindo.

Jamaa, L. (2014). Perlindungan Korban Kekerasan Dalam Rumah Tangga Dalam Hukum Pidana Indonesia. Jurnal Cita Hukum, 2(2).

Mansur, M. A. (2007). Dikdik dan Elisatris Gultom. Urgensi Perlindungan Korban Kejahatan Antara Norma dan Realita. Jakarta: PT Raja

Makarao, M. T., Bukamo, W., \& Azri, S. (2013). Hukum Perlindungan Anak dan Penghapusan Kekerasan dalam Rumah Tangga. Rineka Cipta.

Muhid, A., Fauziyah, N., Khariroh, L. M., \& Andiarna, F. (2019). Quality of Life Perempuan Penyintas Kekerasan Seksual: Studi Kualitatif. Journal of Health Science and Prevention, 3(1): 47-55.

Noviani UZ, Arifah R, Cecep, Humaedi S.(2018). Mengatasi dan Mencegah Tindak Kekerasan Seksual Pada Perempuan Dengan Pelatihan Asertif. Jurnal Penelitian \& PPM 5(1):1-110.

Sarong, AH \& Lubis, NAF. (2019). The Child Rights In Islamic Law With A Special Focus On Aceh. Petita: Jurnal Kajian Ilmu Hukum Dan Syariah, 4(1).

Simatupang, N. Faisal. (2017). Hukum Perlindunan Anak. Medan: Pustaka Prima Passalbessy, J. D. (2010). Dampak Tindak Kekerasan Terhadap Perempuan dan Anak Serta Solusinya. Jurnal Sasi, 16 (3).

Probosiwi, R., \& Bahransyaf, D. (2015). Pedofilia dan kekerasan seksual: Masalah dan perlindungan terhadap anak. Sosio Informa, 1 (1).

Rusni, R. (2017). Fenomena Kekerasan Seksual Terhadap Anak. Shautut Tarbiyah, 22 (2): 51-68.

Siregar, H. (2018). Peranan Pusat Kajian Perlindungan Anak Dalam Menjalankan Hak Asasi Anak Jalanan Ditinjau Dari Pasal 11 Undang-Undang Nomor 23 tahun 2002 tentang Perlindungan Anak. Jurnal Civics: Media Kajian Kewarganegaraan, 15 (1): 9-18.

Susila, J. (2019). Monodualistik Penanganan Tindak Pidana Pelecehan Seksual Perspektif Pembaharuan Hukum Acara Pidana Indonesia. Al-Ahkam: Jurnal Ilmu Syariah dan Hukum, 4(2).

Utami, P. N. (2016). Optimalisasi pemenuhan hak korban kekerasan terhadap perempuan melalui pusat pelayanan terpadu. Jurnal HAM, 7 (1): 55-67.

Wijaya, A., \& Ananta, W. P. (2016). Darurat Kejahatan Seksual. Jakarta: Sinar Grafika.

Pemulihan Trauma Berbasis Masyarakat. (2 Juli 2012). Citing Internet Source URL https://www.kompasiana.com/purnawan/55122d3ca33311ba56ba7f6c/ pemulihan-trauma-berbasis-masyarakat?page=all

\footnotetext{
Atikah Rahmi ${ }^{1}$ \& Hotma Siregar ${ }^{2}$

${ }^{1,2}$ Universitas Muhammadiyah Sumatera Utara

E-mail: ${ }^{1}$ atikahrahmi@umsu.ac.id, ${ }^{2 h}$ otmasiregar@umsu.ac.id
} 